\title{
INNOWACJE JAKO CZYNNIK WARUNKUJĄCY KONKURENCYJNOŚĆ GOSPODARCZĄ NA PRZYKłADZIE GOSPODARKI DANII
}

\begin{abstract}
Streszczenie
Postępujące procesy globalizacyjne, nieustannie zmieniające się oczekiwania klientów czy sytuacja na rynku wymuszają na podmiotach gospodarczych bycie innowacyjnym. Innowacje bowiem wiąże się z możliwością wprowadzenia nowych innowacyjnych produktów bądź usług na rynek, zastosowania bardziej efektywnej i oszczędnej metody produkcji itp. To, z kolei, niesie za sobą szanse rozwoju firmy, wejścia na nowe rynki zbytu albo zwiększenia udziału na dotychczas zajmowanych. Rezultatem tego jest często zwiększenie produkcji czy też okazja do stworzenia nowych miejsc pracy. Natomiast w odniesieniu do sytuacji gospodarczej może to skutkować natomiast wzrostem PKB bądź zmniejszeniem poziomu bezrobocia, co wyraźnie wpływa na kondycję gospodarczą.

Celem niniejszego artykułu jest próba przedstawienia roli, jaką innowacje odgrywają w jednej z najbardziej innowacyjnych, konkurencyjnych i najlepiej rozwiniętych gospodarek na świecie, ze zwróceniem uwagi na innowacyjność i miejsce Danii w gospodarce światowej.
\end{abstract}

Słowa kluczowe: innowacje, kondycja gospodarcza, konkurencyjność

\section{INNOVATION AS THE DETERMINANT OF ECONOMIC COMPETITIVENESS ON THE EXAMPLE OF THE DANISH ECONOMY}

\section{Summary}

The ongoing processes of globalization, constantly changing customer's needs or market conditions are forcing traders to be innovative. Innovations in fact associated with the introduction of new innovative products or services on the market, the use of more efficient and cost-effective production methods, etc. This in turn brings business development opportunities, entry into new markets or increase the share of the previously occupied. This is often the result of increased production, or an opportunity to create new jobs. With regard to the economic situation however this may result in an increase or decrease in the GDP level of unemployment, which clearly affects the economic condition.

The purpose of this article is an attempt to present the role that innovation plays in one of the most innovative, competitive and most developed economies in the world, with a focus on innovation and place of Denmark in the global economy.

Key words: innovation, economic condition, competitiveness

1 dr Joanna Prystrom - Wydział Zarządzania, Politechnika Białostocka; e-mail: j.prystrom@ pb.bialystok.pl. 


\section{Wstęp}

W obliczu wyzwań XXI wieku, nieustannie postępujących procesów globalizacyjnych czy też stale zmieniających się sytuacji w gospodarkach i oczekiwań klientów, innowacje okazują się być wielce istotnym narzędziem umożliwiającym przetrwanie w tym burzliwym otoczeniu.

Dzięki aktywności innowacyjnej, realizujacy ją podmiot jest w stanie utrzymać się na rynku i przezwyciężyć zagrożenie nieustannie nasilającej się konkurencji [Tushman, 1997, s. 4].

Innowacje, a dokładniej rzecz ujmując, aktywność innowacyjnych podmiotów gospodarczych wiąże się z możliwością wprowadzenia nowych innowacyjnych produktów bądź usług na rynek, zastosowania bardziej efektywnej i oszczędnej metody produkcji itp. To, z kolei, niesie ze sobą szanse rozwoju firmy, wejścia na nowe rynki zbytu albo zwiększenia udziału na dotychczas zajmowanych. Rezultatem tego jest często zwiększenie produkcji, czy też okazja do stworzenia nowych miejsc pracy. Natomiast w odniesieniu do sytuacji gospodarczej może to skutkować wzrostem PKB lub zmniejszeniem poziomu bezrobocia, co wyraźnie wpływa na kondycję gospodarczą.

Celem niniejszego artykułu jest próba przedstawienia roli, jaką innowacje odgrywaja w jednej z najbardziej innowacyjnych, konkurencyjnych i najlepiej rozwiniętych gospodarek na świecie, ze zwróceniem uwagi na innowacyjność i miejsce Danii w gospodarce światowej.

\section{Innowacje - istota i znaczenie dla rozwoju gospodarczego}

Pojęcie innowacji jest rozumiane i rozpatrywane niezwykle szeroko. Odnosi się do wszystkich sfer życia, począwszy od nowych rozwiązań dotyczących sfery gospodarczej czy społecznej, skończywszy na nowych prądach myślowych i kulturalnych. W potocznym rozumieniu innowacja oznacza coś nowego i innego od dotychczasowych rozwiązań. Dosyć często może kojarzyć się z potrzebą zmiany na lepsze. Ogólnie rzecz ujmując, innowacja to: wprowadzenie czegoś nowego, rzecz nowo wprowadzona, nowość, reforma. Takie tłumaczenie obowiazuje zarówno w terminologii polskiej, jak również w innych państwach. Wynika to z silnego oddziaływania źródeł łacińskich, albowiem słowo innowacja w języku łacińskim to innovatio, czyli „odnowienie” [Prystrom, 2008, s. 153].

Za ojca i prekursora innowacji jest uznawany J. Schumpeter, który na początku XX wieku upowszechnił to pojęcie w naukach ekonomicznych. Rozwój gospodarczy przedstawial jako proces napędzanych przez innowacje pozytywnych zmian, rozłożony w pewnym przedziale czasu. W jego mniemaniu, innowacja oznaczała nową kombinację istniejących możliwości i odznaczała się wysoce ważną funkcją rozwojowa, przede wszystkim w odniesieniu do stanu gospodarczego [Fagerberg, 2005, s. 6]

Za przykład innowacji Schumpeter podawał: wprowadzanie nowego produktu, modyfikację dotychczasowych, wprowadzanie nowej metody produkcji, uzyskanie 
nowych źródeł i możliwości, wykorzystanie nietkniętych do tej pory obszarów i rynków czy też nowe sposoby organizacji biznesu [Schumpeter, 1932, s. 66].

Można stwierdzić, iż innowacje to zarówno wprowadzenie do produkcji wyrobów nowych lub też doskonalenie produktów już istniejących, wprowadzenie nowego czy udoskonalenie istniejącego procesu produkcyjnego oraz wprowadzenie nowej organizacji jakiegoś przemysłu, np. „stworzenie monopolu bądź jego złamanie”. Przez innowacje Schumpeter rozumiał także otwarcie nowego rynku, na którym dany proces, produkt albo usługa do tej pory nie były nikomu znane, zastosowanie nowego sposobu sprzedaży lub zakupu czy też zdobycie i zastosowanie nowego źródła surowców lub półfabrykatów [Schumpeter, 1960, s. 104].

\section{Wpływ innowacji na gospodarkę}

\section{RYSUNEK 1.}

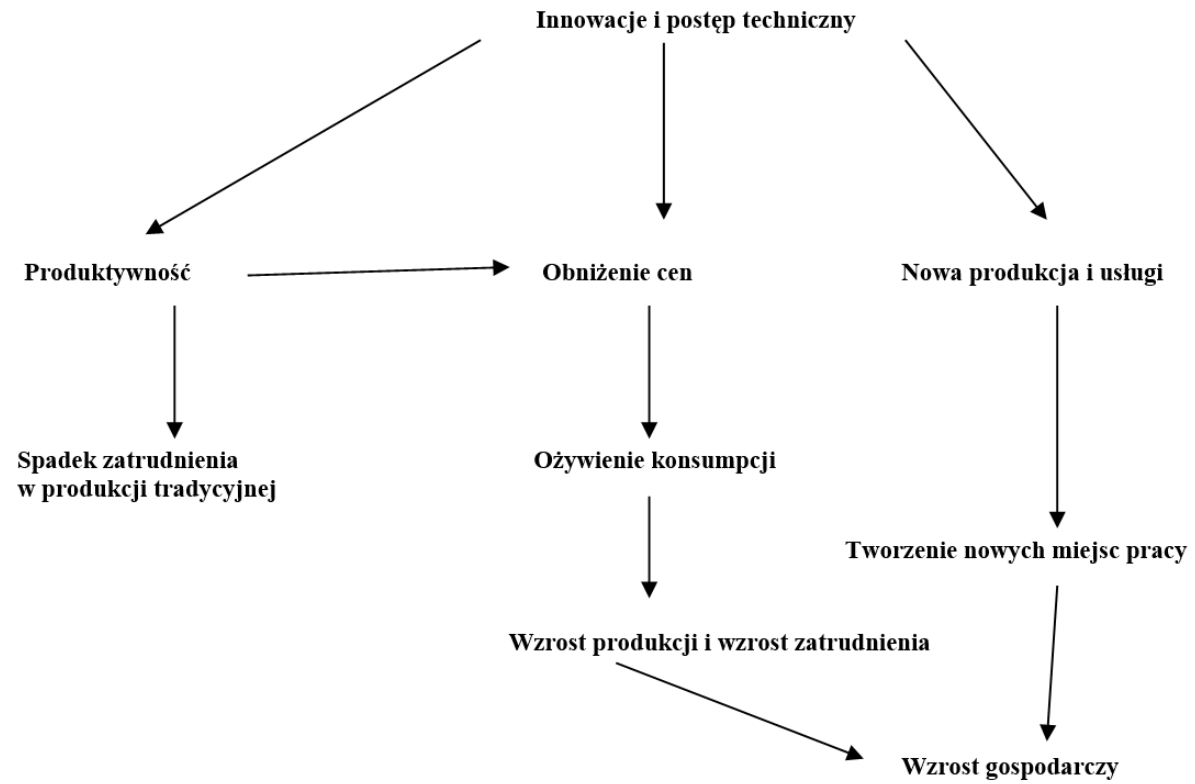

Źródło: opracowanie własne na podstawie: [Krelle, 1989, s. 22].

Oczywistym wydaje się fakt, że podstawą innowacyjności i konkurencyjności krajowej gospodarki jest innowacyjność krajowych podmiotów gospodarczych. Przedsiębiorstwo, aby się rozwijać, potrzebuje innowacji. Firmom, które nie zdają sobie z tego sprawy, grozi zastój i w rezultacie przegrana z konkurencją oraz wykluczenie z rynku. Jak pisał Ch. Freeman: nie uprowadzać innowacij, to znaczy umierać [Freeman, 1973, s. 21].

Mechanizm innowacji i jego wpływ na strukturę gospodarki przejawia się w ciagłych zmianach ilościowych w proporcjach zużywanych czynników w procesach produkcji oraz w zmianach jakościowych tych czynników. Prowadzi to z jednej strony do doskonalenia wyrobów, nadawania im nowych cech użytkowych, obniżania jednos- 
tkowych kosztów produkcji, z drugiej zaś - do pojawienia się nowych produktów. Nagromadzenie wiedzy, doświadczeń, opanowanie nowych technologii umożliwia przyśpieszenie procesu innowacyjnego przy zwiększonych korzyściach strukturalnych i korzyściach skali produkcji [Ciborowski, 2004, s. 22-23].

Analizując rysunek 1., można stwierdzić, iż innowacyjność krajowych podmiotów gospodarczych jest determinantą kondycji gospodarczej kraju. Wśród efektów oddziaływania innowacji wyróżnia się możliwość zwiększenia produkcji, rozwój funkcjonujących dotychczas lub otwieranie nowych przedsiębiorstw, co, z kolei, skutkuje szansa utworzenia nowych miejsc pracy i zmniejszenia poziomu bezrobocia, a to prowadzi między innymi do wzrostu gospodarczego.

Należy dodać, iż o konkurencyjności gospodarczej decyduje również między innymi nieustanna walka pomiędzy przedsiębiorstwami i gospodarkami w celu uzyskania większej liczby posiadanych zasobów, które umożliwiają zdobycie przewagi konkurencyjnej na danych segmentach rynku zarówno w skali krajowej, jak i międzynarodowej. Dojście do tego typu przywództwa wymaga od rywalizujących podmiotów gospodarczych konieczności innowacyjności, uczenia się i zdobywania wiedzy [Hunt, 2000, s. 135].

Jak wspomniano, innowacje są wszechobecne na wielu płaszczyznach życia, zarówno gospodarczego, społecznego, jak i wielu innych. Jeśli chodzi o kondycję gospodarczą kraju i jego rozwój, najistotniejszymi wydają się innowacje gospodarcze [Prystrom, 2012, s. 13].

Działalność innowacyjna prowadzi do rozwoju firm dzięki pojawieniu się możliwości ich rozbudowy i ekspansji na nowe rynki bądź zwiększeniu udziału na dotychczas zajmowanych. Wówczas skutkuje to koniecznością stworzenia nowych miejsc pracy i determinuje strukturę oraz rozmiary konsumpcji, determinując tym samym rozwój gospodarczy [Prystrom, 2012, s. 13].

\section{Innowacyjność gospodarki Danii}

W obecnych czasach niezwykle istotną rolę w budowaniu silnej pozycji na globalnym rynku zaczynają odgrywać zasoby o charakterze niematerialnym, czyli wiedza i innowacyjność. Poziom tych dwóch czynników w decydujący sposób wpływa na krajowy rynek oraz jego kierunek rozwoju. Konkurencyjność jest tworzona przez: poziom edukacji, zdolność do adaptowania nowoczesnych technologii i do ich dalszego rozwoju oraz poziom wydatków na badania i rozwój [Innowacyjność w gospodarce...].

Główną instytucją odpowiadająca za aktywność badawczo - rozwojowa, innowacyjność, edukację i kształcenie obywateli jest Ministerstwo Nauki, Innowacji i Szkolnictwa Wyższego. Kluczowym założeniem Ministerstwa jest uczynienie z Danii jednej z najbardziej przedsiębiorczych i opartych na wiedzy gospodarek, posiadających jedno z najlepiej wykształconych społeczeństw na świecie. Ministerstwo składa się z:

- Duńskiej Agencji Edukacji Międzynarodowej;

- Duńskiej Agencji do spraw Nauki, Technologii i Innowacji;

- Duńskiego Uniwersytetu i Agencji Wyższej Edukacji [Thomas, 2011, s. 15-16]. 
TABELA 1. Innowacyjność gospodarki duńskiej na tle grupy najbardziej innowacyjnych państw w latach 2007-2011

\begin{tabular}{|c|c|c|c|c|c|}
\hline $\begin{array}{c}\text { Lokata } \\
\text { w ran- } \\
\text { kingu }\end{array}$ & Rok 2007 & Rok 2008 & Rok 2009 & Rok 2010 & Rok 2011 \\
\hline $\mathbf{1 .}$ & Szwecja & Szwecja & Szwecja & Szwecja & Szwecja \\
\hline $\mathbf{2 .}$ & Szwajcaria & Finlandia & Finlandia & Dania & Dania \\
\hline $\mathbf{3 .}$ & Finlandia & Niemcy & Niemcy & Finlandia & Niemcy \\
\hline $\mathbf{4 .}$ & Irlandia & Dania & $\begin{array}{c}\text { Wielka } \\
\text { Brytania }\end{array}$ & Niemcy & Finlandia \\
\hline $\mathbf{5 .}$ & Dania & $\begin{array}{c}\text { Wielka } \\
\text { Brytania }\end{array}$ & Dania & $\begin{array}{c}\text { Wielka } \\
\text { Brytania }\end{array}$ & Belgia \\
\hline $\mathbf{6 .}$ & Japonia & Austria & Austria & Belgia & $\begin{array}{c}\text { Wielka } \\
\text { Brytania }\end{array}$ \\
\hline $\mathbf{7 .}$ & Niemcy & Islandia & Luksemburg & Austria & Holandia \\
\hline $\mathbf{8 .}$ & $\begin{array}{c}\text { Wielka } \\
\text { Brytania }\end{array}$ & Luksemburg & Belgia & Holandia & Austria \\
\hline $\mathbf{9 .}$ & USA & Belgia & Islandia & Islandia & Luksemburg \\
\hline $\mathbf{1 0 .}$ & Luksemburg & Francja & Francja & Luksemburg & Islandia \\
\hline
\end{tabular}

Źródło: [Innovation Union Scoreboard, 2012, s. 7; Innovation Union Scoreboard, 2010, s. 4; European Innovation Scoreboard (EIS)..., 2010, s. 6; European Innovation Scoreboard, 2008, s. 4; European Innovation Scoreboard..., 2008, s. 7].

Za sukces duńskiego sektora innowacji w znacznej mierze odpowiada Duńska Agencja do spraw Nauki, Technologii i Innowacji (DASTI), która została utworzona z inicjatywy rządu w 2006 roku. Głównym zadaniem pracowników zatrudnionych w instytucji jest przełożenie języka politycznych deklaracji i prawnych regulacji na realne działania z zakresu: innowacji, gospodarki i kultury. Wyniki pokazują, że duńscy specjaliści znają się na swoim fachu jak nikt inny. Duńskiej Agencji do spraw Nauki, Technologii i Innowacji podlegają jednostki odpowiedzialne za realizacje działań w poszczególnych sektorach [Garski]:

- Duńska Rada do spraw Niezależnych Badań;

- Duńska Rada do spraw Badań Strategicznych;

- Duńska Rada do spraw Technologii i Innowacji;

- Duński Komitet do spraw Szkoleń Badawczych (działający pod kontrolą Duńskiego Komitetu do spraw Koordynacji Badań Naukowych).

Omawiając innowacyjność duńskiej gospodarki, wypada wspomnieć że w drugiej połowie 2007 roku został opublikowany rządowy plan „Innovation Danmark” na lata 2007-2010. Został on przygotowany przez Duńską Radę Nauki, Technologii i Innowacji (DASTI), podległą Ministerstwu Nauki, Technologii i Innowacji w Danii. Głównym zadaniem duńskiego DASTI jest promocja rozwoju innowacji w gospodarce przez: propagowanie osiagnięć wiedzy, koordynację współpracy firm i instytucji, komercjalizację prac badawczych i rozwiązań technicznych oraz wspieranie rozwoju przedsiębiorczości z wykorzystaniem nowoczesnych rozwiązań technologicznych. Przedstawione przez rząd założenia zawieraja ponad 70 inicjatyw, których 
wdrożenie ma umożliwić utrzymanie się przez Danię w gronie najbardziej konkurencyjnych i innowacyjnych gospodarek świata. Na realizację planu przeznaczono z budżetu państwa 3 mld DKK $\mathrm{DK}^{2}$ [Innowacyjność w gospodarce...].

W ramach powyższego planu, wyznaczono dwa główne cele duńskiej polityki innowacyjności [Innowacyjność w gospodarce...]:

1. Stały wzrost liczby firm duńskich o charakterze innowacyjnym w wyniku efektywnego transferu wiedzy do 2010 roku - charakter innowacyjny ma posiadać $45 \%$ małych, $55 \%$ średnich i $75 \%$ dużych firm;

2. Wzrost zatrudnienia osób wysoko wykształconych przez duńskie MSP w wyniku zwiększonego współdziałania instytucji naukowo-badawczych i MSP w 2010 roku - 12\% małych i 70\% średnich przedsiębiorstw ma zatrudniać osoby posiadające wykształcenie wyższe - obecnie osoby z wyższym wykształceniem zatrudnia odpowiednio 10\% i 65\% firm duńskich.

O innowacyjności krajowej gospodarki decyduje wiele różnorodnych czynników. Do najważniejszych można zaliczyć: kapitał ludzki, funkcjonujące otoczenie instytucjonalne wspierające działalność innowacyjnych podmiotów gospodarczych czy też finansowanie tego typu aktywności.

Analizując poziom nakładów finansowych przeznaczanych na działalność $\mathrm{B}+\mathrm{R}$, można zauważyć, iż wśród najbardziej innowacyjnych gospodarek na przestrzeni 10 lat wysokość finansowania w Danii nie była najwyższa. Pod tym względem zdecydowanymi liderami okazały się Finlandia i Szwecja (zob. tabela 2.).

TABELA 2.

Nakłady na działalność B + R wśród najbardziej innowacyjnych gospodarek na świecie (\% PKB) w latach 2001 - 2010

\begin{tabular}{|l|c|c|c|c|c|c|c|c|c|c|}
\hline Rok & $\mathbf{2 0 0 1}$ & $\mathbf{2 0 0 2}$ & $\mathbf{2 0 0 3}$ & $\mathbf{2 0 0 4}$ & $\mathbf{2 0 0 5}$ & $\mathbf{2 0 0 6}$ & $\mathbf{2 0 0 7}$ & $\mathbf{2 0 0 8}$ & $\mathbf{2 0 0 9}$ & $\mathbf{2 0 1 0}$ \\
\hline Dania & 2,39 & 2,51 & 2,58 & 2,48 & 2,46 & 2,48 & 2,58 & 2,85 & 3,06 & 3,06 \\
Finlandia & 3,32 & 3,36 & 3,44 & 3,45 & 3,48 & 3,48 & 3,47 & 3,70 & 3,93 & 3,88 \\
Szwecja & 4,13 & - & 3,80 & 3,58 & 3,56 & 3,68 & 3,40 & 3,70 & 3,60 & 3,40 \\
Niemcy & 2,47 & 2,50 & 2,54 & 2,50 & 2,51 & 2,54 & 2,53 & 2,69 & 2,82 & 2,82 \\
Belgia & 2,08 & 1,94 & 1,87 & 1,86 & 1,83 & 1,86 & 1,89 & 1,97 & 2,03 & 1,99 \\
Wielka & 1,79 & 1,79 & 1,75 & 1,68 & 1,73 & 1,75 & 1,78 & 1,79 & 1,86 & 1,78 \\
Brytania & & & & & & & & & & \\
Austria & 2,05 & 2,12 & 2,24 & 2,24 & 2,46 & 2,44 & 2,51 & 2,67 & 2,72 & 2,76 \\
Luksem- & - & - & 1,65 & 1,63 & 1,56 & 1,66 & 1,58 & 1,57 & 1,66 & 1,63 \\
burg & & & & & & & & & & \\
Islandia & 2,95 & 2,95 & 2,82 & - & 2,77 & 2,99 & 2,68 & 2,64 & - & - \\
\hline
\end{tabular}

Źródło: opracowanie własne na podstawie: [Nakłady na driałalność...].

Bardzo silną pozycję w świecie mają duńskie uniwersytety. W rankingach najlepszych szkół wyższych regularnie pojawiają się: Uniwersytet Kopenhaski oraz Uniwersytet Aarhus. Z kolei, za jedną z najbardziej renomowanych uczelni ekonomicznych uchodzi Uniwersytet Południowej Danii. Natomiast według raportu „Research

$21 \mathrm{DKK}=$ 0,5491 PLN (kurs średni waluty obcej według NBP z dnia 12.10.2012 roku). 
Eurobarometer 2010", duńscy naukowcy sa jednymi z częściej cytowanych w tak prestiżowych magazynach, jak „Nature” czy „Science” [Garski].

Rozwój duńskiego sektora innowacji napędza w dużej mierze wspólpraca międzynarodowa. Duńskie Ministerstwo do spraw Nauki, Technologii i Innowacji posiada własne Centra Innowacji w Dolinie Krzemowej, Szanghaju i Monachium, a także specjalne biuro w Brukseli. Działania z zakresu polityki innowacyjnej koordynuje w kraju Duńska Rada do spraw Technologii, do której zadań należą w szczególności [Garski]:

- komercjalizacja wiedzy;

- $\quad$ regionalne strategie innowacji;

- $\quad$ wspieranie współpracy środowisk naukowych z biznesowymi;

- implementacja rozwiązań z zakresu ICT w biznesie i przemyśle;

- infrastruktura badawcza i przemysłowa.

Jedną $z$ determinant zdolności innowacyjnej określa się pracowników sektora $B+R$, którzy bardzo często stają się autorami nowatorskich odkryć czy opracowań. Można zauważyć, iż pod tym względem Duńczycy plasują się dość daleko za prowadzącymi Niemcami, Szwedami, Finami czy Belgami (zob. tabela 3.).

Niezwykle ważny wydaje się fakt, iż opracowany przez londyński instytut Centre for European Reform (CER $)^{3}$ ranking krajów Unii Europejskiej z punktu widzenia budowania konkurencyjnej gospodarki wskazuje na wysoki poziom wykorzystania potencjału nauki w Danii. Ocenie podlegało 27 krajów, w tym 25 członkowskich oraz 2 nowe kraje Wspólnoty - Bułgaria i Rumunia. Raport brytyjskiego instytutu CER pozytywnie ustosunkował się do duńskiej gospodarki. Brytyjscy eksperci uznali za liderów wdrażania Strategii Lizbońskiej kraje skandynawskie, na czele z Dania [Innowacyjnośc w gospodarce...].

Duński model to połączenie wysokiego poziomu wzrostu gospodarczego, wysokiego zatrudnienia i wysokich standardów ochrony społecznej. Raport podkreśla, że zatrudnienie w tym kraju było o 12 punktów procentowych wyższe niż średnio w Unii Europejskiej, a Dania ma także najwyżej ocenione osiagnięcia w takich ważnych kategoriach jak: równość społeczna, edukacja, badania naukowe i rozwój oraz ochrona środowiska. Ten duński model w wysokiej ocenie CER jest przez ekspertów uważany za wzorcowy i godny naśladownictwa [Innowacyjność w gospodarce...].

\footnotetext{
${ }^{3}$ Kluczowym założeniem działalności londyńskiego ośrodka CER (Centre for European Reform) jest przyczynienie się do wzmocnienia funkcjonowania i rozwoju Unii Europejskiej praktycznie we wszystkich aspektach, począwszy od kwestii klimatycznych, na bezpieczeństwie kończąc.
} 
TABELA 3. Osoby zatrudnione $\mathbf{w}$ działalności $B+\mathbf{R}$ w najbardziej innowacyjnych krajach, w latach $2005-2011$ (w ekwiwalentach pełnego wymiaru czasu pracy) ${ }^{4}$

\begin{tabular}{|l|r|r|r|r|r|r|r|}
\hline Rok & \multicolumn{1}{|c|}{$\mathbf{2 0 0 5}$} & \multicolumn{1}{|c|}{$\mathbf{2 0 0 6}$} & \multicolumn{1}{|c|}{$\mathbf{2 0 0 7}$} & \multicolumn{1}{|c|}{$\mathbf{2 0 0 8}$} & \multicolumn{1}{|c|}{$\mathbf{2 0 0 9}$} & \multicolumn{1}{|c|}{$\mathbf{2 0 1 0}$} & \multicolumn{1}{c|}{$\mathbf{2 0 1 1}$} \\
\hline Dania & 43499 & 44878 & 46897 & 58589 & 54391 & 53191 & 57170 \\
Finlandia & 57471 & 58257 & 56243 & 56698 & 56069 & 55897 & 54526 \\
Szwecja & 77704 & 78715 & 74437 & 79549 & 75849 & 77418 & 78480 \\
Niemcy & 475278 & 487935 & 506450 & 522688 & 534565 & 549042 & 562600 \\
Belgia & 53517 & 55714 & 57963 & 58476 & 59756 & 59851 & 59991 \\
Wielka Brytania & 324916 & 334804 & 343855 & 342086 & 347483 & 319487 & 358583 \\
Austria & 47625 & 49377 & 53252 & 58014 & 56438 & 58519 & 60378 \\
Luksemburg & 4392 & 4376 & 4604 & 4652 & 4711 & 4889 & 4988 \\
Islandia & 3226 & 3415 & 2982 & 3117 & 3753 & - & - \\
\hline
\end{tabular}

Źródło: opracowanie własne na podstawie: [Zatrudnieni w driałalności badawcrej...].

O poziomie innowacyjności krajowej gospodarki może również świadczyć aspekt uzyskiwania patentów. Przez ponad 20 lat Duński Urząd Patentów i Znaków Towarowych wykonał i rozwinął szeroka gamę usług w przedsiębiorstwach europejskich, jak i w pozostałych regionach świata. Jest wiele firm prawniczych oraz międzynarodowych przedsiębiorstw, które korzystaja z usług Urzędu Patentowego, który posiada specjalistów technicznych, obejmujących wszystkie dziedziny. Projekty, którymi zajmuje się Duński Urząd Patentów i Znaków Towarowych dotyczą między innymi zdolności we wszystkich dziedzinach własności intelektualnej, rozwoju bazy danych czy egzekwowania praw własności intelektualnej. Głównym celem Duńskiego Urzędu Patentowego jest zagwarantowanie szybkości postępowania w udzielaniu patentów. Ograniczone zostały formalności postępowania, dzięki wprowadzeniu systemu aplikacji elektronicznej. Urząd zapewnia opinię w języku duńskim, jak i angielskim, a cała procedura aplikacyjna trwa średnio około 3,5 roku. Nowością jest inicjatywa

${ }^{4}$ Są to jednostki przeliczeniowe służące do ustalania faktycznego zatrudnienia w działalności B+R. Jeden ekwiwalent pełnego czasu pracy (w skrócie EPC) oznacza jeden osobo-rok poświęcony wyłącznie na działalność $\mathrm{B}+\mathrm{R}$. Zatrudnienie w działalności $\mathrm{B}+\mathrm{R}$ w ekwiwalentach pełnego czasu pracy ustala się na podstawie proporcji czasu przepracowanego przez poszczególnych pracowników w ciagu roku sprawozdawczego przy pracach $\mathrm{B}+\mathrm{R} \mathrm{w}$ stosunku do pełnego czasu pracy obowiązującego $\mathrm{w}$ danej instytucji na danym stanowisku pracy. Przyjmuje się że:

a) pracownik pracujący na całym etacie poświęcający w ciagu roku sprawozdawczego na działalność $\mathrm{B}+\mathrm{R}$ :

- $\quad 90 \%$ lub więcej ogólnego czasu pracy = 1,0 EPC;

- $\quad 75 \%$ ogólnego czasu pracy $=0,75 \mathrm{EPC}$;

- $\quad 50 \%$ ogólnego czasu pracy $=0,5 \mathrm{EPC}$;

b) pracownik pracujący na 0,5 etatu i poświęcający na działalność $\mathrm{B}+\mathrm{R}$ :

- $\quad 90 \%$ lub więcej swojego ogólnego czasu pracy = 0,5 EPC;

- $\quad 50 \%$ swojego ogólnego czasu pracy = 0,25 EPC;

c) pracownik zatrudniony w danej jednostce w roku sprawozdawczym przez 6 miesięcy na całym etacie i poświęcający $90 \%$ lub więcej swojego ogólnego czasu pracy na działalność $\mathrm{B}+\mathrm{R}=0,5 \mathrm{EPC}$

d) osoba wykonująca prace B $+\mathrm{R}$ na podstawie umowy zlecenia lub umowy o dzieło - pełny, faktyczny czas pracy w roku sprawozdawczym "ze wszystkich umów", podany jako odpowiedni ułamek rocznego czasu pracy. 
PPH (Patent Prosecution Highways) ${ }^{5}$ mająca na celu usprawnienie procedur rozpatrywania wniosków o udzielenie patentu [Innowacyjność w gospodarce...].

TABELA 4.

Liczba wniosków patentowych w Danii oraz Unii Europejskiej w latach 2000 - 2007 w przeliczeniu na liczbę mieszkańców

\begin{tabular}{|l|c|c|c|c|c|c|c|c|}
\hline Rok: & $\mathbf{2 0 0 0}$ & $\mathbf{2 0 0 1}$ & $\mathbf{2 0 0 2}$ & $\mathbf{2 0 0 3}$ & $\mathbf{2 0 0 4}$ & $\mathbf{2 0 0 5}$ & $\mathbf{2 0 0 6}$ & $\mathbf{2 0 0 7}$ \\
\hline $\begin{array}{l}\text { Liczba duńskich wnios- } \\
\text { ków patentowych }\end{array}$ & 1725 & 1768 & 1819 & 1779 & 1847 & 1658 & 1503 & 1658 \\
\hline $\begin{array}{l}\text { Liczba wniosków pa- } \\
\text { tentowych w Unii } \\
\begin{array}{l}\text { Europejskiej (z uwzględ- } \\
\text { nieniem Danii) }\end{array}\end{array}$ & 714 & 816 & 778 & 867 & 984 & 1174 & 1246 & 1408 \\
\hline
\end{tabular}

Źródło: [Innowacyjność w gospodarce...].

Przejrzystość oraz szybkość procedury, a także znaczne ułatwienia, jak np. aplikowanie elektroniczne, przekłada się na statystyki, w których Dania posiada jedna $z$ najwyższych w Europie liczbę zgłoszonych patentów w przeliczeniu na liczbę mieszkańców [Innowacyjność w gospodarce...].

Jeśli chodzi o liczbę innowacyjnych podmiotów gospodarczych funkcjonujących na terenie Danii w 2008 roku tego typu jednostki stanowiły ok. 44,4\% ogółu funkcjonujących przedsiębiorstw.

TABELA 5.

Liczba innowacyjnych podmiotów gospodarczych w najbardziej innowacyjnych krajach w 2008 roku, które wprowadziły innowacje produktową ${ }^{6}$

\begin{tabular}{|l|c|}
\hline & Liczba przedsiębiorstw \\
\hline Dania & $44,4 \%$ \\
Finlandia & $37,3 \%$ \\
Szwecja & $50,4 \%$ \\
Niemcy & $26,0 \%$ \\
Belgia & $47,5 \%$ \\
Wielka Brytania & - \\
Austria & $49,5 \%$ \\
Luksemburg & $40,6 \%$ \\
Islandia & - \\
\hline
\end{tabular}

Źródło: opracowanie własne na podstawie: [Europe in figures..., 2011].

\footnotetext{
${ }^{5}$ Inicjatywa opiera się na dostępnych, we współpracujących ze sobą urzędach przyspieszonych procedurach badania wniosków o udzielenie patentów, które umożliwiają wnioskodawcom z obu krajów uzyskanie równoległych patentów w sposób szybszy i bardziej efektywny. System pozwala urzędom na korzystanie z pracy wcześniej wykonanej przez drugi urząd, co zmniejsza całkowite nakłady pracy oraz podnosi jakość udzielonego patentu. Obecnie, w ramach PPH Królestwo Danii posiada umowy partnerskie z: USA, Niemcami, Wielką Brytania, Australia, Kanada, Koreą i Europejskim Urzędem Patentowym.

${ }^{6}$ Innowacje produktowe wiążą się z udoskonaleniem towaru już produkowanego lub z wprowadzeniem do oferty nowego produktu. Ich przeciwieństwem są innowacje procesowe, które polegają na wprowadzeniu zmian w: procesie produkcyjnym, metodach wytwarzania czy też otwarciu nowej linii produkcyjnej itd.
} 
Analizując innowacyjność gospodarki duńskiej, warto zwrócić uwagę na kierunek tejże aktywności. Godny uwagi jest fakt, iż Duńczycy inwestują przede wszystkim w branże biotechnologiczną i farmaceutyczną. Duńska Rada do spraw Badań Strategicznych pod koniec 2010 roku przeznaczyła prawie 9 mln EUR na utworzenie pierwszego w kraju centrum badań nad komórkami macierzystymi, zakładając, że Dania może stać się potentatem w tej dziedzinie. Z tego przedsięwzięcia skorzystają nie tylko instytucje publiczne, ale i prywatne przedsiębiorstwa [Garski].

Należy dodać, że w przypadku innowacyjności Danii, istotną rolę odgrywa Duńska Rada do spraw Technologii i Innowacji działająca pod kontrolą Ministerstwa Nauki, Technologii i Innowacji. Instytucja ta administruje szereg inicjatyw dążących do promocji innowacji i upowszechniania wiedzy między instytucjami naukowymi a przedsiębiorstwami. Rada przy współpracy z Ministerstwem i po przejściu szerokiej krajowej procedury konsultacji z organizacjami, instytucjami i podmiotami innowacji opracowała czteroletni plan działania o nazwie „Innovation Dania 2010 2013”, wytyczający główne inicjatywy polityki innowacji w Danii [Thomas, 2011, s. 15-16].

Do ważniejszych założeń planu można zaliczyć m.in. wyraźne zaznaczenie, że prywatny sektor $\mathrm{B}+\mathrm{R}$ musi stanowić minimum $2 \%$ krajowego $\mathrm{PKB}$ i duńskie przedsiębiorstwa powinny być jednymi z najbardziej innowacyjnych na świecie. Co więcej, duńskie podmioty gospodarcze muszę być nieustannie i jeszcze bardziej innowacyjne, wliczając w to wszystkie jednostki z sektora MSP. Ponadto, gospodarka Danii powinna plasować się w czołowej trójce europejskiego rankingu innowacyjności. Zgodnie z wytycznymi planu, istotną kwestię odgrywa również upowszechnianie wiedzy i ciagłej współpracy między sferą badań a przemysłem, które stale należy wzmacniać [Thomas, 2011, s. 15-16].

\section{Miejsce i rola Danii w gospodarce światowej}

Dania składa się z Półwyspu Jutlandzkiego oraz ponad 400 wysp, między innymi wyspy Zelandii, na której jest położona Kopenhaga - największe miasto duńskie i stolica kraju. Dania liczy sobie około 5,3 mln mieszkańców, z czego ok. 1,7 mln mieszka w stolicy kraju i jej okolicach. Kraj ten posiada dobrze rozbudowana, nowoczesną sieć komunikacyjną, a dzięki budowie tuneli i mostów pod i nad Wielkim Bełtem oraz cieśniną Sund łączącymi Danię ze Szwecją, stała się ona krajem odgrywającym ważną rolę na północy Europy [Dania w zarysie, 2006, s. 4].

Dania jest krajem rozwiniętym gospodarczo o bardzo wysokim standardzie życia. Niezależnie od sposobów obliczania dochodu na głowę mieszkańca, kraj ten sytuuje się wśród najbogatszych krajów świata. Ponadto, infrastruktura w Danii uważana jest za najbardziej rozwiniętą w świecie, a kraj ten, według opinii specjalistów posiada najlepszą w Europie sieć dystrybucji. Godną uwagi ciekawostką jest fakt, iż przesyłki pocztowe docierają do adresatów w ciagu 24 godzin [Informacje o kraju - Dania]

Dania, będąc jednym z pięciu najbogatszych państw Unii Europejskiej z PKB per capita przekraczającym 40,3 tys. euro, pozostaje najdroższym państwem członkowskim Unii Europejskiej. Wysoki poziom rozwoju kraju wynika przede wszystkim z: 
przyjętego modelu gospodarczego, zaawansowania technologicznego i dobrze rozpoznanych europejskich i - coraz częściej - również globalnych nisz rynkowych. Mocne strony gospodarki Danii to sektory: rolnictwa i przetwórstwa żywności, konsultingu, elektroniki, infrastruktury IT, technologii środowiskowych, energii odnawialnej, ogrzewania rozproszonego, ropy i gazu, farmaceutyki oraz transportu [Informator ekonomicziny o krajach swiata...].

Głównym sektorem gospodarki duńskiej jest sektor usług, w którym zatrudnienie znajduje około $76 \%$ siły roboczej i tworzy on ponad $72 \%$ PKB. Istotne znaczenie ma tu sektor publiczny, w którym jest zatrudniona blisko połowa osób pracujących w usługach. Państwo, gminy i regiony sa głównymi pracodawcami w rozbudowanym sektorze: opieki socjalnej, lecznictwie, szkolnictwie i administracji publicznej. Dużą rolę odgrywają także firmy prywatne. Znaczna część działalności największej duńskiej firmy, koncernu A.P.Møller-Mærsk jest związana z usługami, transportem (Mærsk - największa kontenerowa firma świata) czy handlem (Dansk Supermarked), [Informator ekonomic zny o krajach swiata...].

W Danii znajduje się także największa w Europie firma zajmująca się sprzątaniem - ISS International Service Systems, firma Sophus Berendsen - gigant na rynku usług pralniczych. Światową renomą cieszą się także duńskie firmy doradcze i projektanckie, jak: COWI Consult, Rambøll czy Niras, a także biura architektoniczne, jak Utzon-Arkitekter czy Henning Arsen Architects A/S. Dania z pomoca oficjalnego programu rządowego „Invest in Denmark” [www.investindenmark.dk] zdecydowanie promuje dalszy rozwój usług, w tym: lokalizację na jej terytorium centrów logistyczno-dystrybucyjnych, usług software'owych oraz kompleksowego świadczenia usług, tzw. „Shared Service Centers” [Informator ekonomiczny o krajach śniata...].

Jeśli chodzi o sferę przemysłu, Dania jest krajem ubogim w surowce mineralne inne niż ropa naftowa i gaz naturalny. Stąd rozwój przemysłu, który nastąpił po drugiej wojnie światowej, nie był związany z występowaniem konkretnych surowców. Ostatnie lata przyniosły dynamiczny rozwój gałęzi przemysłu obejmujących wysoko wyspecjalizowana produkcję (tworzywa sztuczne i metale), przez wykorzystanie nisz rynkowych, a także branż opartych na osiagnięciach naukowych, jak np.: produkcja specjalistycznych chemikaliów i farmaceutyków, elektronika profesjonalna i projekty inżynierskie. Najważniejsze gałęzie przemysłu Danii to: wydobycie ropy i gazu, przemysł stoczniowy, odzieżowy i obuwniczy, farmaceutyczny, maszynowy oraz elektroniczny. Duński sektor przemysłowy zatrudnia około $21 \%$ siły roboczej i ma ponad dwudziestosześcioprocentowy udział w PKB [Informator ekonomiczny o krajach swiata...].

Omawiając miejsce i rolę gospodarki duńskiej na arenie międzynarodowej, należy zwrócić uwagę na wyraźną tendencją w Danii, którą jest recesja w przemysłach materiało-intensywnych (m. in. przetwórstwo żywności, tekstylia), podczas gdy zaawansowane technologicznie, wiedzo-intensywne sektory, takie jak biotechnologia, klimat, technologie informatyczne, elektronika odnotowały wzrost [Informator ekonomiczny o krajach swiata...].

Prawie połowa całkowitej produkcji obejmuje profesjonalny sprzęt elektroniczny (m.in.: silniki i generatory elektryczne, przyrządy pomiarowe, urządzenia medyczne). 
Pozostała część to głównie elektronika użytkowa, wyróżniająca się wysokim standardem i nowoczesnym designem (np. telefony czy też aparaty słuchowe) [Informator ekonomiczny o krajach śmiata...].

Warto dodać, iż duński przemysł elektroniczny stanowia producenci o wysokim stopniu specjalizacji. Najbardziej znanym przedstawicielem duńskiej elektroniki konsumpcyjnej jest firma Bang \& Olufsen. Dania jest także największym w Europie producentem kolumn głośnikowych i głośników, produkowanych głownie przez firmę Jamo. Ponadto, prawie 30\% przemysłu elektronicznego w Danii obejmuje elektronika medyczna, głównie produkcja aparatury pomiarowej i sprzętu laboratoryjnego [Przemyst w Danii...].

Godny uwagi jest również fakt, że Dania to jedno z pierwszych państw na świecie, które wprowadziło krajową ustawę o ochronie środowiska (Environmental Protection $A c t)$. Duńskie elektrownie i turbiny wiatrowe odznaczają się najlepszą wydajnościa na świecie. W ostatnich latach znacznie rozwinął się sektor zarządzania odpadami. Około 2/3 odpadów jest poddawane recyklingowi, a 1/4 jest używana do produkcji ciepła i energii elektrycznej, jedynie $5 \%$ odpadów ląduje na wysypiskach śmieci [Informator ekonomic zny o krajach śniata...].

Dzięki swojej polityce energetycznej, Dania początkowo w 99\% uzależniona od zagranicznych źródeł ropy, dziś jest całkowicie samowystarczalna w zakresie dostaw energii. Dodatkowo, przez ostatnie 25 lat, duńska gospodarka zanotowała siedemdziesięcioprocentowy wzrost, przy prawie stałym poziomie zużycia energii na jednostkę PKB. Udział energii odnawialnej w ogólnym zużyciu energii wzrósł z 3\% w 1980 roku do ponad 18\% w 2009 roku. Czynniki te umożliwiły Danii zredukowanie emisji $\mathrm{CO}_{2}$ o prawie $14 \%$ od 1990 roku. Ma to również przełożenie na eksport, gdyż duński przemysł wiatrowy jest światowym liderem w tej dziedzinie $(25 \%$ udziału, sam Vestas 14\%). Prowadzone sa także intensywne badania w dziedzinie technologii przyszłości, takich jak ogniwa paliwowe i wodorowe [Informator ekonomiczny o krajach swiata...].

Najważniejszymi przedstawicielami duńskiego przemysłu wydobywczego są: państwowy koncern DONG Energy oraz należąca do największego duńskiego konsorcjum A.P. Møller-Mærsk A/S spółka Mærsk Olie og Gas [Præemyst w Danii].

Należy dodać, że duński przemysł farmaceutyczny jest jednym z najbardziej nowoczesnych i innowacyjnych na świecie. Dania sytuuje się wśród największych eksporterów produktów farmaceutycznych, dlatego duży nacisk kładzie się na inwestycje $\mathrm{w}$ prace $\mathrm{B}+\mathrm{R}$. Z ponad 400 różnych produktów farmaceutycznych, wytwarzanych przez duńskie firmy, najważniejsze sa: insulina, antybiotyki i leki psychotropowe. Państwo duńskie stało się jednym z najsilniejszych w zakresie badań dotyczących nauk przyrodniczych w Europie. Zajmuje drugie miejsce w światowym rankingu w dziedzinie patentów biotechnologicznych. Dania plasuje się również na najwyższej pozycji w Europie w zakresie wielkości inwestycji kapitału podwyższonego ryzyka (liczonego jako procent PKB) w dziedzinie głównie biotechnologii oraz na trzecim miejscu w Europie w kwestii rozwoju handlu lekami. Duńsko-szwedzka współpraca określana jako Medicon Valley, skupia ponad 60\% skandynawskiego przemysłu farmaceutycznego [Informator ekonomiczny o krajach śniata...]. 
Oprócz dużych koncernów, jak wytwarzający niemal 50\% światowej insuliny Novo Nordisk, H. Lundbeck czy Novoenzyms, w Danii działa wiele mniejszych firm wykorzystujących niewielkie nisze rynkowe. Specjalnością duńskiego przemysłu farmaceutycznego, oprócz insuliny, sa: enzymy, leki hormonalne, psychotropowe i antybiotyki [Informator ekonomiczny o krajach świata...].

Rozwój przemysłu farmaceutycznego i biotechnologicznego jest jednym z priorytetów duńskiej polityki przemysłowej. W usytuowanej w okolicach Kopenhagi i szwedzkiego Lund „Medicon Valley” funkcjonuje blisko 100 firm biotechnologicznych, co przekształciło region Øresund w miejsce o największym nasyceniu firm biotechnologicznych w Europie [Przemyst w Danii].

Dania jest jednym z najbardziej rozwiniętych państw na świecie w dziedzinie telekomunikacji i technologii informatycznych. Liberalizacja rynku telekomunikacyjnego oznacza, iż Dania posiada jedne z najtańszych usług telekomunikacyjnych pośród państw OECD i jest jednym z liderów w zakresie użytkowania Internetu, usług publicznych on-line oraz e-biznesu. Dania posiada ponad 9000 przedsiębiorstw branży teleinformatycznej, gdzie zatrudnionych jest prawie 100000 osób [Informator ekonomiczny o krajach swiata...].

Dania jest krajem o gospodarce otwartej, uzależnionej od sytuacji na rynkach światowych, dlatego szczególnie duży wpływ na jej sytuację miał międzynarodowy kryzys gospodarczy. W 2008 roku odnotowano jego skutki w postaci objawów recesji gospodarczej, a w 2009 roku jej dochód narodowy spadł w stopniu nienotowanym od drugiej wojny światowej, o prawie 6\% [Wspótpraca gospodarcza: Dania].

O miejscu i kondycji gospodarki Danii na arenie światowej decydują także eksport $\mathrm{i}$ import. Ograniczona wielkość rynku krajowego, na wczesnym etapie, skłoniła duńskich producentów do poszukiwania odbiorców za granica. W rezultacie, duński przemysł wytwórczy jest wysoce zorientowany na eksport. Zrównoważony bilans handlowy to jedna z cech niedawnego wzrostu gospodarczego. Rynek Unii Europejskiej stanowi prawie $70 \%$ odbiorców duńskich produktów, a najbliżsi sąsiedzi są najważniejszymi klientami. Dla przykładu: Niemcy, Szwecja i Wielka Brytania to $40 \%$ odbiorców duńskiego eksportu, gdzie tylko Niemcy stanowia 18\%. Nowe rynki zostały otwarte w Europie Środkowej i Wschodniej i na Dalekim Wschodzie [Wspótpraca gospodarcza: Dania].

Duńskie produkty rolne, takie jak: ser, wieprzowina, ryby, masło i zboże są eksportowane od ponad wieku. Rolnictwo wytwarza bezpośrednio około 17\% duńskiego eksportu. Znaczący jest również eksport maszyn i sprzętu dla przemysłu rolnego. Pozostałe $80 \%$ to głównie maszyny i sprzęt farmaceutyczny oraz elektroniczny [Wspótpraca gospodarcza: Dania].

Dane handlu zagranicznego Danii za 2010 rok wyraźnie wskazują wzrost eksportu oraz importu o odpowiednio $9,8 \%$ i $8,4 \%$ w porównaniu z rokiem poprzednim. Wymiana handlowa towarami z państwami członkowskimi Unii Europejskiej objęła 68\% całej duńskiej wymiany towarowej. Eksport do krajów Unii Europejskiej stanowił 64,7\% łącznego eksportu z Danii, import z tych krajów 70,9\% całkowitego duńskiego importu, natomiast 5,7\% wymiany handlowej przypadało na Norwegię. Handel zagraniczny Danii można określić jako wysoce skoncentrowany, 
dziesięciu największych partnerów handlowych tworzy około 70\% całej wymiany towarowej, zarówno w imporcie jak eksporcie. Od lat największym partnerem handlowym Danii są Niemcy - w 2010 roku duński eksport do Niemiec równał się około 16,8\% całości, zaś duński import w tym samym okresie wyniósł 20,7\%. Drugim największym partnerem handlowym Danii jest Szwecja, do której duński eksport stanowił 13,4\%, a import 13,4\% odpowiednio całkowitego eksportu i importu towarowego. Trzecia pozycję w eksporcie zajmuje Wielka Brytania, a w imporcie Chiny, które wyprzedziły w 2010 roku Holandię. Chiny w szybkim tempie zwiększyły swój udział w duńskim imporcie. W ciąu ostatniej dekady udział chińskich towarów w imporcie zwiększył się z około $2 \%$ do 5,6\% w 2008 roku oraz 7,6\% w 2010 roku i stale rośnie, Chiny stały się trzecim największym krajem, z którego pochodzi import do Danii [Współpraca gospodarcza: Dania].

Omawiając miejsce i rolę gospodarki duńskiej w gospodarce światowej, godna uwagi jest kwestia konkurencyjności gospodarczej ${ }^{7}$. Najlepszym kryterium wydaja się tzw. mierniki międzynarodowej konkurencyjności. Jednymi z najogólniejszych miar są udział w światowym produkcie brutto mierzony siłą nabywczą i poziom rozwoju gospodarczego mierzony dochodem realnym per capita [Prystrom, 2012, s. 9].

W rankingach konkurencyjności, według indeksu GCI Światowego Forum Ekonomicznego, Szwecja obok Stanów Zjednoczonych, Szwajcarii i Danii odgrywa rolę wiodąca. Zgodnie z Global Competitiveness Report 2008-2009, Dania, Stany Zjednoczone, Szwajcaria i Szwecja są jednymi z najbardziej konkurencyjnych gospodarek na świecie. Do grona dziesięciu najlepszych i najbardziej konkurencyjnych krajów zaliczono także: Singapur, Finlandię, Niemcy, Holandię, Japonię oraz Kanadę [The Global Competitiveness..., 2008, s. 10].

TABELA 6.

Światowy Ranking Konkurencyjności według WEF (Global Competitiveness Index) 2010-2012

\begin{tabular}{|l|c|c|}
\hline Państwo & $\begin{array}{c}\text { Miejsce w rankingu 2010 - } \\
\text { 2011 (wśród 139 państw) }\end{array}$ & $\begin{array}{c}\text { Miejsce w rankingu 2011 - 2012 } \\
\text { (wśród 144 państw) }\end{array}$ \\
\hline Szwajcaria & 1. & 1. \\
Szwecja & 2. & 3. \\
Singapur & 3. & 2. \\
USA & 4. & 5. \\
Niemcy & 5. & 6. \\
Japonia & 6. & 9. \\
Finlandia & 7. & 4. \\
Holandia & 8. & 7. \\
Dania & 9. & $\mathbf{8 .}$ \\
Kanada & 10. & 9. \\
\hline
\end{tabular}

Źródło: [Schwab, 2010, s. 15; Schwab, 2012, s. 13].

7 W celu oceny konkurencyjności gospodarczej można zastosować rankingi konkurencyjności sporządzane przez: Międzynarodowy Instytut Rozwoju Ekonomicznego, Światowe Forum Ekonomiczne, nowojorską fundację Heritage Fundation, Unię Europejską czy też Organizację Współpracy Gospodarczej. Najbardziej prestiżowymi rankingami są te sporządzone przez IMD i WEF. 
W tabeli 6. zaprezentowano zestawienie najbardziej konkurencyjnych gospodarek świata w latach 2010-2011 i 2011-2012 według rankingu WEF.

Można zauważyć, że najbardziej konkurencyjnymi gospodarkami na przestrzeni dwóch ostatnich lat są Szwajcaria, Szwecja i Singapur. Gospodarka duńska w ostatnich latach również wyraźnie zalicza się do grona najbardziej konkurencyjnych gospodarek na świecie, w zestawieniu zajmując pozycję 9. i 8.

Godny uwagi jest także sporządzany corocznie raport IMD, dotyczący światowej konkurencyjności (WCY) ${ }^{8}$, który jest uznawany za jedną z najpowszechniejszych i dokładniejszych rocznych deskrypcji konkurencyjności państw. Służy on analizie on funkcjonowanie poszczególnych gospodarek i podtrzymywaniu ducha rywalizacji wśród potencjalnych konkurentów, biorąc pod uwagę takie czynniki, jak: infrastruktura, jakość rządów, warunki ekonomiczne oraz wydajność biznesu [dokument elektroniczny, tryb dostępu: http://www.imd.ch/research/publications/wcy/index.cfm, data wejścia: 18.07.2008], (zob. tabela 7.).

TABELA 7.

\section{Światowy Ranking Konkurencyjności według IMD w latach 2011 - 2012}

\begin{tabular}{|l|c|c|}
\hline Państwo & Miejsce w rankingu 2011 & Miejsce w rankingu 2012 \\
\hline Hong Kong & 1. & 1. \\
USA & 1. & 2. \\
Szwajcaria & 5. & 3. \\
Singapur & 3. & 4. \\
Szwecja & 4. & 5. \\
Kanada & 7. & 6. \\
Tajwan & 6. & 7. \\
Norwegia & 13. & 8. \\
Niemcy & 10. & 9. \\
Katar & 8. & 10. \\
Holandia & 14. & 11. \\
Luksemburg & 11. & 12. \\
Dania & $\mathbf{1 2 .}$ & $\mathbf{1 3 .}$ \\
\hline
\end{tabular}

Źródło: [IMD announces its 2012...].

Warto zwrócić uwagę na dokładniejszą analizę duńskiej gospodarki w Światowym Rankingu Konkurencyjności. Sytuację Danii przedstawiono według podstawowych wskaźników (infrastruktura, stabilność makroekonomiczna, zdrowie i edukacja), czynników wspomagających konkurencyjność (szkolnictwo wyższe i szkolenia, rynek pracy, rynek dóbr i usług, rynek finansowy) oraz według czynnika innowacyjności gospodarki (zob. tabela 8.).

\footnotetext{
${ }^{8}$ To jest World Competitiveness Yearbook.
} 
TABELA 8.

Dania według Światowego Indeksu Konkurencyjności 2012 - 2013

\begin{tabular}{|l|c|}
\hline \multicolumn{1}{|c|}{ Czynnik konkurencyjości } & Lokata w rankingu \\
\hline Otoczenie instytucjonalne & 14. \\
Infrastruktura & 16. \\
Środowisko makroekonomiczne & 32. \\
Zdrowie i wykształcenie podstawowe & 29. \\
Wyższa edukacja i szkolenia & 14. \\
Efektywność produktowa rynków & 19. \\
Efektywność rynku pracy & 8. \\
Zaawansowanie rynku finansowego & 30. \\
Zdolność technologiczna & 3. \\
Rozmiar krajowego rynku & 53. \\
Zaawansowanie biznesu & 9. \\
Innowacje & 12. \\
\hline
\end{tabular}

Źródło: opracowanie własne na podstawie: [Schwab, 2012, s. 152].

Można zauważyć, że duńska gospodarka najlepiej wypada pod względem: zdolności technologicznej, efektywności funkcjonowania rynku pracy, zaawansowania biznesu i innowacyjności, plasując w ten sposób Danię w pierwszej dwunastce najbardziej konkurencyjnych gospodarek na świecie.

\section{Podsumowanie}

Jak już wspomniano, innowacyjność krajowych podmiotów gospodarczych jest determinantą kondycji gospodarczej kraju, gdyż przekłada się między innymi na sytuację panującą na krajowym rynku pracy i wielkość PKB [Prystrom, 2012, s. 13].

Przedstawione informacje potwierdzają fakt, że gospodarka duńska jest zaliczana do grona najbardziej innowacyjnych, a tym samym konkurencyjnych gospodarek na świecie.

W związku z powyższym, godne uwagi jest także zestawienie konkurencyjności gospodarczej pod względem innowacyjności i zdolności innowacyjnej, zaprezentowane w tabeli 9.

Z tabeli 9. wynika, że sytuacja gospodarki duńskiej, jeśli chodzi o konkurencyjność pod względem innowacyjności i zdolności technologicznej, jest zróżnicowana. W rankingu konkurencyjności wyznaczonej przez innowacyjność gospodarcza, Dania uplasowała się na miejscu 12. wśród 144 krajów. Duńczycy zdecydowanie lepiej wypadli w przypadku zdolności technologicznej, zajmując 3. miejsce w zestawieniu. 
TABELA 9. Światowy Ranking Konkurencyjności pod względem innowacyjności i zdolności technologicznej według WEF (Global Competitiveness Index) 2011 - 2012

\begin{tabular}{|l|c|c|c|}
\hline \multicolumn{4}{|c|}{ Filary konkurencyjności } \\
\hline \multicolumn{2}{|c|}{ Innowacyjność } & \multicolumn{2}{c|}{ Zdolność technologiczna } \\
\hline Państwo & Lokata w rankingu & Państwo & Lokata w rankingu \\
\hline Szwajcaria & 1. & Szwecja & 1. \\
Japonia & 2. & Luksemburg & 2. \\
Finlandia & 3. & Dania & $\mathbf{3 .}$ \\
Niemcy & 4. & Hong Kong & 4. \\
Szwecja & Singapur & 5. \\
Holandia & 5. & Szwajcaria & 6. \\
USA & 6. & Wielka Brytania & 7. \\
Izrael & 7. & Islandia & 8. \\
Wielka Brytania & 8. & Holandia & 9. \\
Austria & 9. & Finlandia & 10. \\
Singapur & 10. & USA & 11. \\
Dania & 11. & Irlandia & 12. \\
\hline
\end{tabular}

Źródło: [Schwab, 2012, s. 14, 18-19].

Można pokusić się o stwierdzenie, że Dania swój sukces pod względem innowacyjności gospodarczej zawdzięcza skoncentrowaniu się na czterech kluczowych obszarach działań. Są to:

1. nieustanna współpraca pomiędzy sferą biznesu i B+R;

2. dostęp do wysoko wykwalifikowanej sily roboczej;

3. sprawnie funkcjonująca infrastruktura między płaszczyzną badawczą a przemysłem;

4. komercjalizacja efektów działalności $\mathrm{B}+\mathrm{R}$ i aktywna przedsiębiorczość [Innovation].

Co więcej, jak wynika z raportu ${ }^{9} \mathrm{ONZ}$, najbardziej szczęśliwe i satysfakcjonujące życie wiodą Duńczycy, Finowie, Norwegowie i Holendrzy [Raport ONZ...].

W związku z powyższym, wypada stwierdzić że odpowiednie dbanie o jakość kapitału ludzkiego, wysokie nakłady na działalność $\mathrm{B}+\mathrm{R}$, nacisk na nieustanną współpracę między sektorem nauki, rządu i biznesu oraz wspieranie przedsiębiorczości i aktywności innowacyjnej wśród krajowych podmiotów gospodarczych umożliwiają osiagnięcie wysokiego poziomu innowacyjności gospodarczej. To, z kolei, przekłada się na możliwość zwiększenia produkcji, rozwój funkcjonujących dotychczas lub otwieranie nowych przedsiębiorstw, co następnie skutkuje szansą utworzenia nowych miejsc pracy i zmniejszenia poziomu bezrobocia, a to prowadzi między innymi do wzrostu gospodarczego i poprawia sytuację kraju na arenie międzynarodowej.

\footnotetext{
${ }^{9}$ Raport został sporządzony przez Earth Institute działający przy Uniwersytecie Columbia.
} 


\section{Literatura}

Ciborowski R. 2004 Wplyw żmian w polityce ekonomičnej i globalizacji na postę technicz飞y $i$ konkurencyjność gospodarki Wielkiej Brytanii, Wydawnictwo Uniwersytetu w Białymstoku, Białystok.

Dania w rarysie 2006, Hanse-Parlament e. V., Institut für Politik und Wirtschaft, Hamburg.

Duńskie ustugi doradče, dokument elektroniczny, tryb dostępu: [http://www.prodenmark. $\mathrm{com} / \mathrm{pl} /$ dunskie-firmy-uslugowe/ doradztwo-uslugi/, data wejścia: 12.11.2012].

Europe in figures - Eurostat yearbook 2011 2011, Publications Office of the European Union, Luxembourg, dokument elektroniczny, tryb dostępu: [http://epp.eurostat.ec.europa.eu/cache/ITY_OFFPUB/KS-CD-11-

001/EN/KS-CD-11-001-EN.PDF, data wejścia: 02.11.2012].

European Innovation Scoreboard (EIS) 2009 2010, European Commission, Belgium, dokument elektroniczny, tryb dostępu: [http://www.proinno-europe.eu/sites/ default/files/page/10/12/EIS\%202009\%20FINAL_updated.pdf, data wejścia: 11.10.2012].

European Innovation Scoreboard 2008. Comparative Analysis Of Innovation Performance, dokument elektroniczny, tryb dostępu: [http://www.ebn.be/assets/assets/private/ policy $/ 5 . \% 20$ eis $\% 20$ report $\% 202008$.pdf, data wejścia: 11.10.2012].

European Innovation Scoreboard 2007. Comparative Analysis of IMD announces its 2012 World Competitiveness Rankings, dokument elektroniczny, tryb dostępu: [http://www.imd.org/ news/IMD-announces-its-2012-World-Competitiveness-Rankings.cfm, data wejścia: 02.11.2012].

Innovation Performance 2008, European Communites, Luxembourg, dokument elektroniczny, tryb dostępu: http://ec.europa.eu/enterprise/policies/innovation/files/proinno/ eis-2007_en.pdf, 11.10.2012].

Fagerberg J. 2005 Innovation a guide to the literature, [w:] The Oxford Handbook of Innovation, (eds.) J. Fagerberg, D.C. Mowery, R.R. Nelson, Oxford University Press, New York.

Freeman Ch. 1973 The Economics of Industrial Innovation, Penguin Books, London.

Garski K. Ambitne plany Duńçykón, dokument elektroniczny, tryb dostępu: http://www.pi.gov.pl/parp/chapter_86197.asp?soid=AD15CA34EE4B4226AF 82E4F6EA705E32, 12.12.2011 r.

Dokument elektroniczny, tryb dostępu: [http://www.imd.ch/research/publications/ wcy/index.cfm, data wejścia: 18.07.2008].

Hunt S.D. 2000 A General Theory of Competition. Resources, Competence, Productivity, Economic Growth, Sage Publications Inc., Thousand Oaks - London - New Dehli.

Informacje o kraju - Dania, dokument elektroniczny, tryb dostępu: http://www.dania. igns.pl/dania.html, data wejścia: 01.11.2012 r.

Informator ekonomiczny o krajach swiata Dania, Ministerstwo Spraw Zagranicznych, dokument elektroniczny, tryb dostępu: [http://copenhagen.trade.gov.pl/pl/denmark, data wejścia: 30.11 .2012$]$. 
Innovation Union Scoreboard 2012, European Commission, Belgium, dokument elektroniczny, tryb dostępu: [http://ec.europa.eu/ enterprise/policies/innovation/files/ius2011_en.pdf, data wejścia: 11.10.2012].

Innovation Union Scoreboard 2010, dokument elektroniczny, tryb dostępu: [http://www.proinno-europe.eu/sites/default/files/docs_EIS2010/IUS_2010_final. pdf, data wejścia: 11.10.2012].

Innowacyjnośc w gospodarce dunskiej, dokument elektroniczny, tryb dostępu: http://copenhagen.trade.gov.pl/pl/analizy-rynkowe/article/detail,2468,Innowa cyjnosc_w_gospodarce_dunskiej.html, data wejścia: 12.12.2011].

Krelle W. 1989 The Future of the World Economy. Economic Growth and Structure Change, IIASA Springer Verlag, Berlin.

Naktady na działalność badawczq i rozpojowa ( $B+R$ ), dokument elektroniczny, tryb dostępu: [http://www.stat.gov.pl/gus/ 5840_11287_PLK_HTML.htm, data wejścia: 12.10.2012].

Prystrom J. 2012 Innowacje w procesie rozwoju gospodarczego. Istota i uwarunkowania, Difin, Warszawa.

Prystrom J. 2012 Innowacyjne determinanty funkcjonowania rynku pracy na prayktadzie gospodarki szwedzkiej, Oficyna Wydawnicza Politechniki Białostockiej, Białystok.

Prystrom J. 2008 Innowacyjność, ,kluczem do sukcesu” - praylktad Volvo Car Corporation, „Optimum. Studia Ekonomiczne”, Nr 2 (38).

Præ̌emyst w Danii, dokument elektroniczny, tryb dostępu: [http://www.infodania.pl/ info/przemysl-w-danii, 20.11.2012].

Raport ONZ: Dania najszcześliwssymm krajem śniata, Polska na 53. miejscu, dokument elektroniczny, tryb dostępu: http://wiadomosci.onet.pl/swiat/raport-onz-danianajszczesliwszym-krajem-swiata-po,1,5086798,wiadomosc.html, data wejścia: 01.11.2012 r.

Schumpeter J. A. 1960 Teoria wrrostu gospodarçego, Polskie Wydawnictwo Naukowe, Warszawa.

Schumpeter J. A. 1932 The Theory of Economic Development, Galaxy Book, New York.

Schwab K. 2012 The Global Competitiveness Report 2012 - 2013, World Economic Forum, Geneva, dokument elektroniczny, tryb dostępu: [http://www3.weforum.org/ docs/WEF_GlobalCompetitivenessReport_2012-13.pdf, data wejścia: 07.11.2012].

Schwab K. 2010 The Global Competitiveness Report 2010 - 2011, World Economic Forum, Geneva, dokument elektroniczny, tryb dostępu: [http://www3.weforum.org/ docs/WEF_GlobalCompetitivenessReport_2010-11.pdf, data wejścia: 21.02.2012].

The Global Competitiveness Report 2008 - 2009, World Economic Forum, Geneva 2008, dokument elektroniczny, tryb dostępu: [http://www.weforum.org/pdf/ GCR08/GCR08.pdf, data wejścia: 13.03.2009].

Thomas Alslev Christensen 2011, BusinessResearch, Development and Innovation in Denmark. - policies and effects, Danish Ministry of Science, Innovation and Higher Education, dokument elektroniczny, tryb dostępu: [http://en.fi.dk/publications/2011/rdan-innovation-in-denmark/RD $\% 20$ and $\% 20$ Innovation $\% 20$ in $\% 20$ Denmark_7\%20 october\%202011.pdf, data wejścia: 12.10.2012]. 
Tushman M. L., Andersen P. C., O’Reilly CH. 1997 Technology cycles, Innovation Streams and Ambidextrous Organizations: Organization Renewal Through Innovation Streams and Strategic Change, [w:] Tushman M. L., Anderson P., Managing strategic innovation and change, Oxford University Press, New York.

Wspótpraca gospodarcza: Dania, dokument elektroniczny, tryb dostępu: http://www.mg.gov.pl/Wspolpraca+z+zagranica/Wspolpraca+gospodarcza+ Polski+z+krajami+UE+i+EFTA/dania.htm, data wejścia: 12.11.2012].

Zatrudnieni w driałalności badawczej $i$ rožnojowej, dokument elektroniczny, tryb dostępu: [http://www.stat.gov.pl/gus/5840_11287_PLK_HTML.htm, data wejścia: 12.10. 2012]. 